\title{
INVESTIGATION OF THE EARLY TRACES OF PEPPER TRADING IN BANTEN AREA, WEST JAVA
}

\section{Investigasi Jejak Awal Perdagangan Lada di Wilayah Banten, Jawa Barat}

\author{
Moh Ali Fadillah \\ Dept. of History Education, Faculty of Teachings and Education Programme \\ University of Sultan Ageng Tirtayasa \\ Jalan Ciwaru Raya Nomor. 25, Serang, Banten, Indonesia \\ alifadilah@untirta.ac.id
}

Received: 12/01/2021; revision: 19/10-16/10/2021; accepted: 01/11/2021

Published online: 25/11/2021

\begin{abstract}
Abstrak
Berbagai sumber sejarah menyebutkan bahwa Banten merupakan salah satu pelabuhan lada untuk pasar Asia dan Eropa pada abad ke-17. Namun pecahan keramik dari periode Tang dan Song-Yuan hasil penggalian di situs Banten Girang membuktikan bahwa aktivitas perdagangan telah dimulai sejak abad X. Permasalahannya, sejarah awal perkebunan lada belum diketahui dengan jelas, oleh karena itu diperlukan suatu kajian untuk mengetahui tentang perdagangan lada pra-Islam di Banten. Kami melakukan survei di pedalaman Banten yang diduga sebagai lahan perkebunan di masa lalu. Pengamatan lapangan telah menemukan kembali jejak lada yang terhubung ke pelabuhan di pantai utara dan barat. Berdasarkan keterkaitannya dengan peninggalan pra-Islam, lada diduga telah dibudidayakan sejak Milenium pertama Masehi seiring dengan masuknya pedagang India dan China melalui Selat Sunda. Hasil analisis kontekstual terhadap jejak arkeologi dan etnografi, telah memberi gagasan bahwa perdagangan lada telah menjadi penggerak utama perekonomian yang dikendalikan oleh kekuasaan politik pesisir utara Jawa yang mungkin telah dimulai pada masa Tarumanagara dan berkembang pada masa kerajaan Sunda-Banten.
\end{abstract}

Kata Kunci: Banten, Sunda, Tarumanagara, Lada hitam.

\begin{abstract}
Various historical sources state that Banten was one of the pepper ports for the Asian and European markets in the $17^{\text {th }}$ century. Ceramic shards from the Tang and Song-Yuan periods at the Banten Girang site prove that trading activities have started since the $10^{\text {th }}$ century. The problem is, the early history of pepper plantations is unknown, therefore a study is needed to gain knowledge about the pre-Islamic pepper trade in Banten. We conducted a survey in the interior of Banten suspected as plantation land in the past. Field observations have rediscovered traces of pepper connected to ports on the north and west coasts. Based on its association with pre-Islamic remains, pepper was supposed to have been cultivated since the first millennium AD along with the arrival of Indian traders through the Sunda Strait. The results of the contextual analysis on archaeological and ethnographic traces, propose the idea that the pepper trade has become the main driver of the economy controlled by the north coast polities of Java which may have started during the Tarumanagara period and developed during the Sundanese kingdom of Banten.
\end{abstract}

Keywords: Banten, Sunda, Tarumanagara, Black pepper.

\section{INTRODUCTION}

Banten's golden age throughout the $17^{\text {th }}$ century is still remembered by the population in various activities. Individual or mass pilgrimages to the former sultanate's capital at the Banten Lama site are a manifestation of the people's perceptions of 
the majesty of the Islamic kingdom. The legend of greatness was undeniably the main magnet of the such visits, mainly focused on mosque complexes and royal cemeteries. However, the sacred view attached to this cultural heritage has gradually changed after archaeological research was carried out four decades ago. The results of this study have influenced the historical awareness of the modern population of Banten, even becoming a historical reference for the establishment of Banten Province in 2000 (Qomaruzzaman-Anees, 2020, pp. 53-54).

The archaeological testimonies at the Banten Lama site transformed generic knowledge into historical narratives that urban society had been established in that place since five centuries ago. The Surasowan palace, a network of canals, city walls and gates, the water channels of Tasikardi and the Kaibon Palace outside the city (Mundardjito et al., 1978, pp. 4-6) and the collection of excavated goods displayed in the Banten Lama museum represent the existence of an Islamic city at the site (Ambary, 1977; Michrob, 1987, p. 174).

In this way, research and preservation of the old city have transformed metaphysical knowledge to empirical facts. The ruins of an old city with a classic concept indeed make people think that political triumph and economic achievement deserve a special place in the romanticism of Banten history. But these archaeological facts, apart from the living monuments of the great mosques, also show that the golden age has ended in complete destruction which often raises essential questions.

Many historians argue that this was due to the stagnation of economic and political functions in the high-level competition in the Southeast Asian maritime network, either because of internal or external conflict factors (Guillot, 1989, p. 65,1992 , p. 149). This historical phenomenon is a challenge that is always interesting to study. Archaeo-historical and geographic research has been able to explain the early phases, developsment and decline of Banten as revealed by archaeologists and historians (Boontharm, 2003, pp. 11-12; Ueda et al., 2016, pp. 92-93).

Starting this short essay, the subject matter of our study is driven by the dialectic of Southeast Asia's maritime political economy, especially in the city and ports of Banten: what made Banten prosperous and how does it relate to the existence of coastal polities before and after the arrival of Islam? The arguments of many experts lead to the undeniable answer, that almost all episodes of Banten's history rest on the spice economy, especially black pepper (Hall, 2014, p. 233), as emphasized by Peter Boomgaard:

"If we look at the places that struck visitors as being the largest of Southeast Asia in the sixteenth and seventeenth centuries, we come up with Malacca, Acheh, and Banten. If the presence of any product had influenced the size and location of at least two (Acheh, Banten) of these three cities, it was pepper, and not rice" (Boomgaard, 2007, 191).

The pepper trade has indeed turned Banten into a large port in the $17^{\text {th }}$ century on the southern route of the Java Sea. With the advancement of the pepper trade, the estuary of the $\mathrm{Ci}$ Banten was transformed into a city that represented its heyday; the link that Denys Lombard emphasized in the formation of the 'Asian networks' (Lombard, 1970, 1996), and which also inspired Anthony Reid to label it 'Age of Commerce' (Reid, 1988, 1990). If we adhere to Mark Braudel's longue durée model (1960), then the historical junctures in the case of Banten should be able to stimulate academic interest in the economic phenomenon of pepper: where and when was the plant called the 'King of Spices' cultivated and how did this affect the political and economic development in the area before the success of the Sultanate of Banten was achieved? This paper will try to find related facts to get an explanation of the early period of the spice trade in the Banten region. 


\section{METHOD}

The above question certainly implies unrealistic ambitions in the study of archeology. The difficulty will also be encountered, instead of drawing conclusions, tracing the pre-Banten Girang pepper trade is very inadequate. Therefore, data on landscapes, environments, traditions, and some archaeological remains associated with ancient exchanges will corroborate initial conjectures. The methodological difficulties are the reasons why this paper does not lead to a well-established synthesis, and just designs a hypothetical bridge for future research: economic archaeology or agricultural archaeology, for example, could become a discourse on systematic research about the beginnings of Banten's pepper economy.

In this study, a complementary survey method was used, namely the study of secondary sources to obtain the latest information from various historical and archaeological reviews. To complement these historical sources, we conducted field observations in several locations where the inhabitants are still planting pepper, i.e., around the slopes of Mounts Karang and Pulosari, and also Lada Bay, and the course of the Ci Liman river. The locations visited belong to the administrative areas of the Regencies of Serang and Pandeglang, Banten Province.

This speculative courage is based on three considerations. First, the availability of primary historical sources covering space and time of our discussion: travel reports, and trade agreement supported by historical analysis are valuable information to summarize related events.

In this context, Claude Guillot's reinterpretation of the text of the agreement between the representatives of the Portuguese rulers and the King of SundaBanten gives a strong signal that at since least the early $16^{\text {th }}$ century pepper has been a main export product (Guillot, 1991, pp. 5376). However, the discovery of Yue-ware from the late Tang Dynasty during excavations at the Banten Girang site could be a suggestion for an earlier date (Guillot et al., 1996, pp. 145-46; Harkantiningsih, 2013, p. 33).

The second consideration, our knowledge is provided by archaeological remains from more ancient periods, although the information is still fragmented from one another it challenges our interest to reconsider its significance. In archaeohistorical studies, we are always trapped in the ambiguity of time, and it seems that there are still 'missing links' in the early phases of Banten historiography: thus, for example, are the various artifacts at the Odel site (Indraningsih, 1986) and the urn graves excavated in Anyer Lor (Sukendar et al., 1982, pp. 22-24; Heekeren, 1956) are still considered to have prehistoric or protohistorical character, while the Purnavarman inscription in District Munjul, South Banten (Damais, 1967, 687-68), located at the same coastline, is generally seen as the starting point of the early phase of Indonesian history. It is therefore important to consider Dalsheimer \& Manguin's analytic review of the traces of Vishnu's followers in Southeast Asia (Dalsheimer \& Manguin 1998, pp. 102103). These two experts offer a 'substantive' view in expressing Tarumanagara's economic vision that covers a wide area. It is possible that the west coast of Banten is included in the scope of his power (cf Wisseman-Christie, 1995, pp. 238-39; Polanyi, 1957).

The third consideration is based on the results of the Banten Cultural Conservation and Preservation Center (BPCB) investigation of several pepper plantations in the interior of Banten (BPCB Team, 2020, pp. 20-28). From the BPCB report, we received information about the distribution of plantations over a wide area. The nature of the field data certainly risks anachronisms but at least provides an opportunity to put forward the argument that pepper farming in this area is likely a 


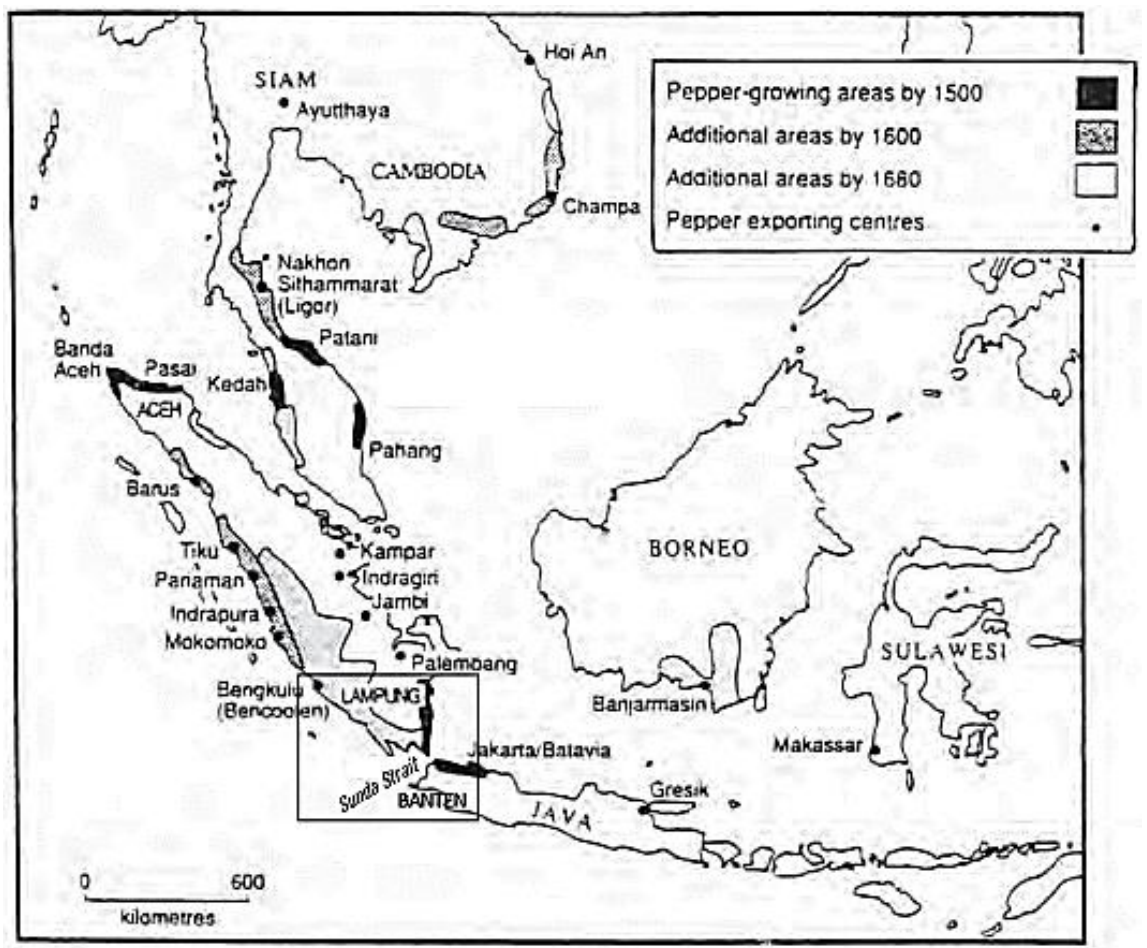

Figure 1. The Pepper Plantation Area of the Banten Sultanate in the $16^{\text {th }}-17^{\text {th }}$ Century (Source: Reid, 1995, p. 99 with the author's addition)

continuation of an old tradition, which has persisted since the dawn of history along with the Indian and Chinese diaspora to Southeast Asia. The results of geographical studies have confirmed the distribution of pepper plants from southern India in the tropics including West Java (Hao et al., 2012, p. 596). Other soursces confirm this, as stated by Wissemen-Christie, referring to the Old Javanese Mananjung charter, that pepper seems to have been planted in Java after the $9^{\text {th }}$ century (Wisseman-Christie, 1998, p. 353). Literary evidence for early Indian shipping is sparse, but it is very likely that Indian traders had sailed to Southeast Asia in the early centuries C.E. (Smith, 1999, pp. 6-7). Thus, these studies allow us to speculate that pepper may have also been grown in the Banten area around the $10^{\text {th }}$ century.

With contextual analysis, we will try to consider all those potential sources as a basis for proposing a working hypothesis. First, following the land and sea communication lines from the north to the south coast, it is possible to propose that pepper plantations could have been located inland, the slopes of Mount Karang and Pulosari that are reachable via the $\mathrm{Ci}$ Banten river, Another possibility could have been a sea route that would give access to the Sunda Strait towards old port of Lada Bay where the $\mathrm{Ci}$ Liman river flows from the Kendeng mountains (Guillot et al., 1996, p. 114). These two ancient routes thus will lead us to possible production centers, or at least pepper farming areas.

The second assumption is that pepper distribution has affected the upstream and downstream agribusiness chains in fertile valleys until one day political forces took control of the port. This local exchange may have started since the arrival of Indian and Chinese traders long before the Sultanate of Banten expanded the area of pepper plantations in southern Sumatra in the beginning of the $16^{\text {th }}$ century.

\section{RESULT AND DISCUSSION \\ 1. Long Term Port for Black Pepper}


Initially, it was difficult to accept the thesis that Banten was a kingdom that once controlled the pepper trade and at its peak carried out a monopoly supported by military power. However, this claim raises the assumption that the Banten movement preceded the VOC approach to pre-colonial economic policy intervention. In fact, the monopoly policy was also applied during the heyday of Srivijaya. As discussed by Billy K.L. So, this trade emporium has controlled important products, especially sandalwood as an export commodity (So, 1998, pp. 298303; cf. Hall, 2010, pp. 463-65). The preIslamic Banten monopoly on black pepper thus might as well have been implemented as an economic strategy.

Interested in getting confirmation of this statement, the late Nurhakim and Fadillah tried to find traces of such a monopoly in the Lampung plantation area. The results of the historical survey and field observations were then presented at a scientific meeting organized by the Indonesian Archaeological Research Center in Bedugul (Bali) entitled: 'Agriculture in
Archeology' (1989). Its presentation is actually more of a political economy perspective on historical events that have undeniably occurred. That pepper farming, widespread in the lowlands along the Seputih, Tulang Bawang and Sekampung rivers (Figure 1), is a contemporary event, but this tradition is a reflection of the past where pepper cultivation was carried out under order of the Banten Sultanate, at least by Sultan Ageng Tirtayasa (1651-1682) to Zainul Asyikin (1753-1773) as outlined in several Piyagem Banten, i.e copper inscriptions in Javanese language (Hazeu 1905, pp. 1-12). This written evidence strengthens indications of the existence of Banten's economic strategy in the southern lowlands of Sumatra (Nurhakim and Fadillah 1990).

Based on epigraphic and ethnographic data, historical interpretations began to doubt the colonial vision that the VOC's monopoly and subordination approaches had actually started in the context of the local political economy (Ueda et al., 2016, pp. 9596; Untoro, 1995, pp. 116-120). The

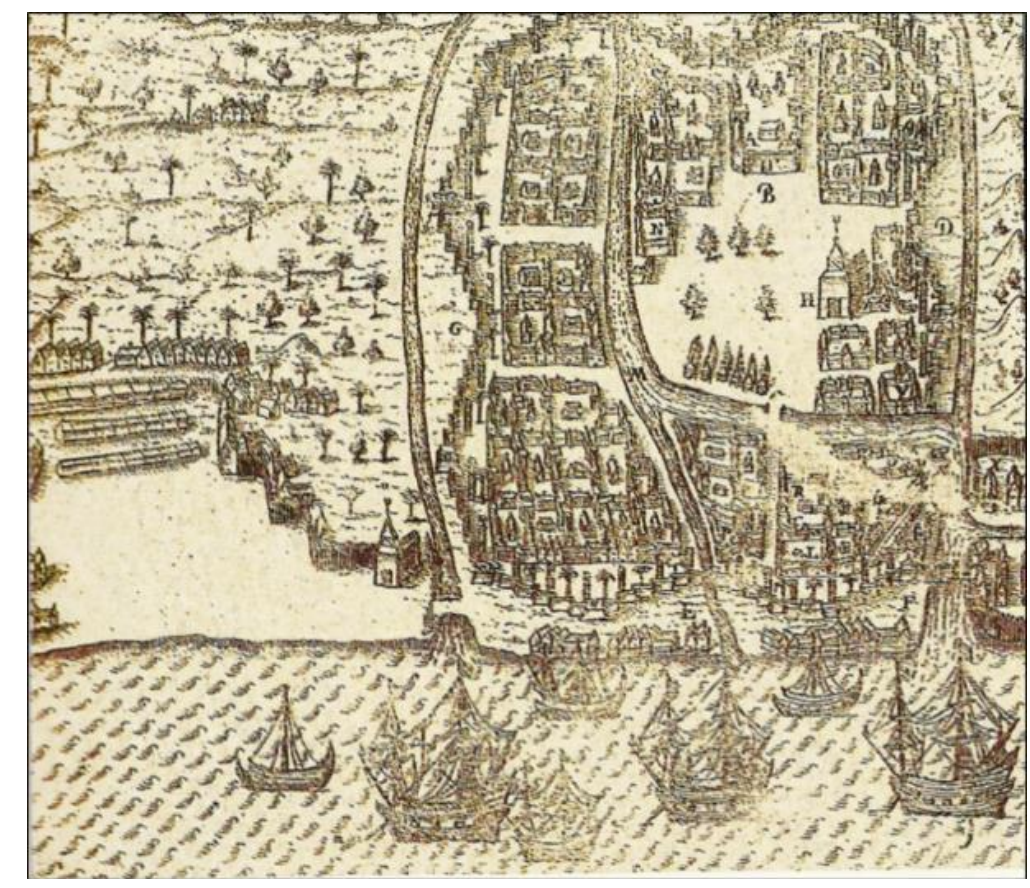

Figure 2. Sketch map of Banten in 1596 (Source: Guillot, Ambary, Dumarçay, 1990) 
problem is whether this intervention was taken when competition began to increase between European, Chinese and local traders, or whether it simply was a result of supply and demand mechanisms in the pepper trade in the world spice network. These questions bring us to two perspectives: was it local political dynamics economic expansion which became the driving force of Banten towards the peak of the spice trade era in Southeast Asian waters? Referring to the records of Lodewycksz (1915, pp. 119-20) it is relevant to say that the rulers of Banten -as was the case in other Southeast Asian ports- had consolidated control over the most productive agricultural land in the Sunda Strait region, where the authorities encouraged upstream farmers to cultivate pepper to meet increasing international demand (Lodewycksz, 1915; WissemanChristie 1995, pp. 96).

Relatively contemporary foreign testimonies such as Cortemunde (1673), the VOC's Dagh Register (1674-1668), the English Indian Office Records (1671) note that up to 1678 there has been a significant evolution of urban space compared to previous years, not only from the physical dimension but also the mental structure of the city of Banten (Guillot, 1989). The physical changes of the city should be in line with increasing prosperity from the pepper business, as illustrated in Claude Guillot's statement below:

" This city is actually the exit of two major international sea routes, namely the Malacca Strait and the Sunda Strait [...] finally the river ends there, not only providing a natural port but also serving as a means of communication with the fertile plains in the interior" (Guillot, 1989, pp. 119).

Referring to the geographical conditions and records of foreigners, the port of Banten undoubtedly had a role known as a cosmopolitan port city as described in the chronicle of Sajarah
Banten that the capital of the kingdom where foreigners only played an additional role. According to Kenneth R. Hall, at that time Banten, with its control over the Sunda Strait (Figure 2), offered an alternative for Indian and Chinese traders to gain profits from the pepper trade, but most importantly that Banten was able to combine the founding of the Muslim community in 1525 with the ruling elite organization network in upstream, downstream, and coastal trading ports (Hall, 214, pp. 233).

The site complex of Banten Lama certainly reflects an extraordinary investment at that time where the city's facilities and infrastructure supported the achievement of social integrity. This reputation has enabled Banten to play an important role in Southeast Asia's trade network in the 'Age of Commerce' (Reid, 1990; cf. Henley, 2015, pp. 120-129).

In view of the archaeological testimony, it cannot be denied that in its golden age Banten was a port of spices that carried out trade relations with places as far as China in the West Pacific and the Bay of Bengal in the Indian Ocean. This reputation was also strengthened by the presence of traders from Persia, India, China, Turkey, Arabia, Abyssinia, which later attracted the interest of Europeans such as the Portuguese with Henrique Leme's fleet in 1522 and Cornelis de Houtman with his first fleet from the Netherlands in 1596 (Hall, 2014, pp. 23435; Lodewycksz, 1915; Guillot, et al., 1990). However, our objective interpretation leads to another fact, namely that in this historical episode there must have been a strategic role for the Banten rulers who contributed to shaping urban civilization and integrating its transformation into one of the spice centers on the north coast of Java (Lombard, 1970, pp. 848) (Figure 3).

With this in mind, it is only natural that Kenneth R. Hall describes Banten as a representation of the Indonesian political 
system; that Banten, benefiting from its strategic location on the northwest coast of Java at the junction of the Java sea route, the South China Sea and the Straits of Melaka, has played an important role as a trading port since the $15^{\text {th }}$ century comparable to e.g. Ayutthaya in Thailand or Banjarmasin in South Kalimantan (Hall, 2014, pp. 232). Based on this opinion and also corroborated by the many trade artifacts at the Banten Girang site, it can be said that trade may have existed in the area before the $10^{\text {th }}$ century.

\section{Upstream - downstream network}

Historical sources have provided two facts: the functioning of the market economy on the one hand and supporting resources on the other. In that context, Banten's trading economy needs access to resource zones to ensure the supply of commodities. That way we can assume there is a communication line between the $\mathrm{Ci}$ Banten river and its upstream network. We assume that the most practical communication route is the $\mathrm{Ci}$ Banten river with its upstream network.

If this river access was used during the Islamic rule in Banten Lama to optimize the flow of goods from upstream to downstream and vice versa, it is very likely that this access was also used by pre-Islamic rulers in Banten Girang to reach resources area. In fact, one of its branches goes to Lebak, continues to Bogor following the branches of several upstream rivers, then joins the old road to the north of Bogor. The Sajarah Banten chronicle relates that Hasanuddin and Sunan Gunung Jati went by road from Banten Girang to Gunung Pulasari, and they brought his troops from Banten Girang to Pakuan (Bogor) (Guillot et al., 1996, pp. 77-78; Fig. 34 \& 35; Mundarjito et al., 1978, p. 1).

Starting from the upper reaches of the Ci Banten, the closest pepper production areas would have been at the northern slope of Mount Karang, where still today plantations areas are found around Pabuaran and Ciomas Districts. From there, through hilly paths, residents could have reached the eastern slopes of Mount Karang by traversing the interior of District Baros to Pasir Peuteuy village, where pepper is still planted. Other traces of pepper production that is still managed traditionally was found extending to the most important route in Banten's ancient history, namely the Gunung Karang and Aseupan routes to the

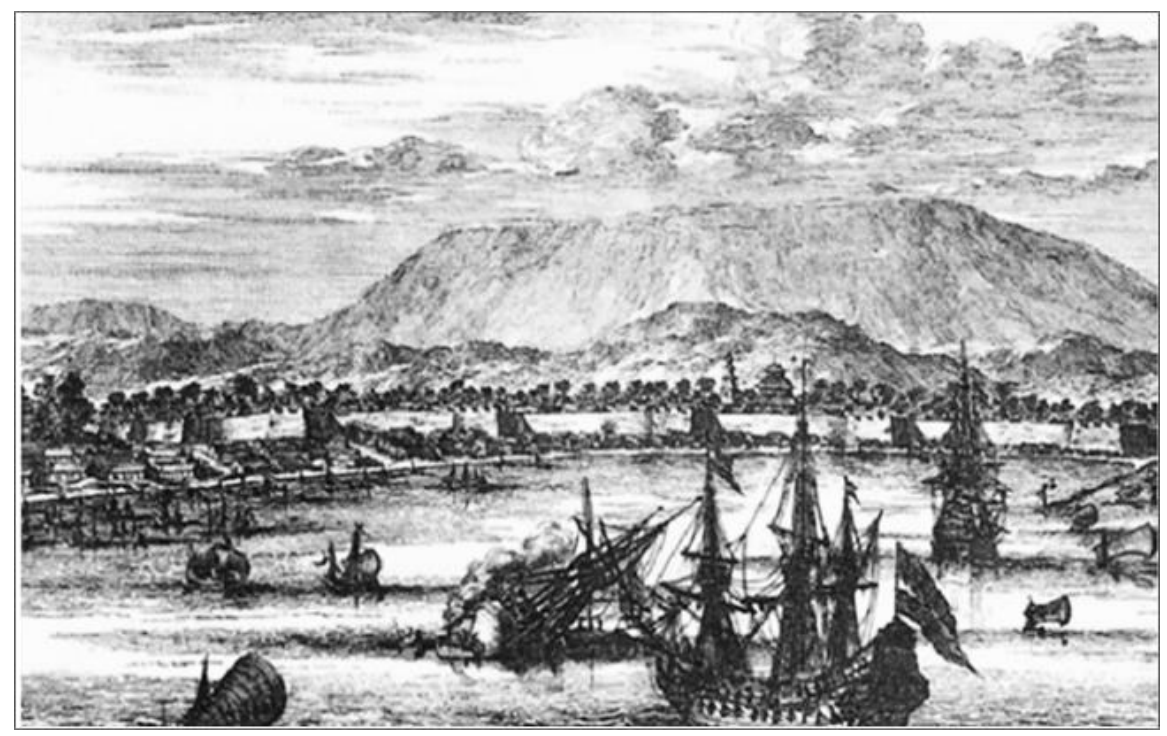

Figure 3. Port of Banten about 1670 (Source: Guillot, Ambary, Dumarçay, 1990) 


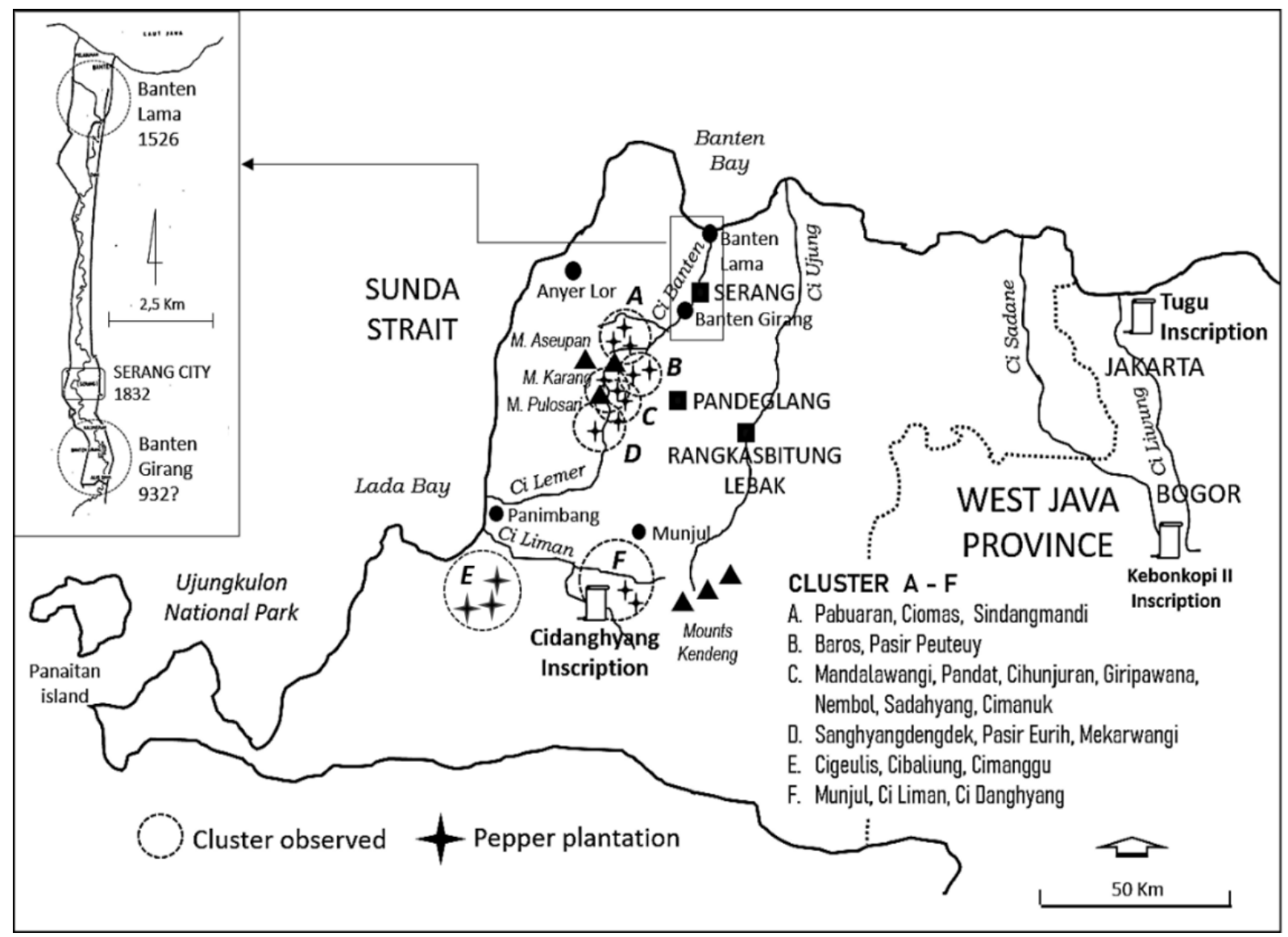

Figure 4. Distribution of pepper plantation in relation to archaeological sites (Source: Fadillah, 2017, 2018, 2020).

Mandalawangi area, allowing easy access to the northern slopes of Pulosari, a mountain that, according to the Banten Chronicle, until the early days of Islamic rule was still considered a 'sacred place' (Djajadinigrat, 1983). Until the end of the $17^{\text {th }}$ century, after Banten's political power was curtailed by the VOC, most pepper plantations were still controlled by the Dutch East India Company (VOC Archives 27-29). The mountainous area of Banten is sknown to be more fertile than the coastal areas and therefore well into in the $18^{\text {th }}$ century remained a pepper producing area. According to the mentioned report, pepper production was concentrated around the slopes of the mountains in Pandeglang: Cimanuk, Munjul, and the Lebak hills, through which the Ci Banten passes (Figure 4). Sources agree that pepper farming activities were still ongoing until the early $19^{\text {th }}$ century; it is even said that the population of the interior was almost as large as the coastal population in the northern region of Banten (Boontharm, 2003, pp. 337; Breugel 1856, pp. 324).

The field survey by the BPCB Team in 2019-2020 covered six sub-districts in Serang and Pandeglang regencies. This journey to the fertile upstream zone reflects local memory that the riverine into the interior of Banten could have well been the main source of pepper coming to the port. The pepper plantations in this location are dense humus land with a planted area of between 0.1 and 0.5 ha per farmer. Data obtained shows that presently the maximum number of trees per plantation is 300 trees with a planting age of 7-10 years. The largest trunk of the pepper trees was found to be 5$7 \mathrm{~cm}$ in diameter (BPCB Team 2020, pp. 101-102). Some important locations that still have springs include the villages of 


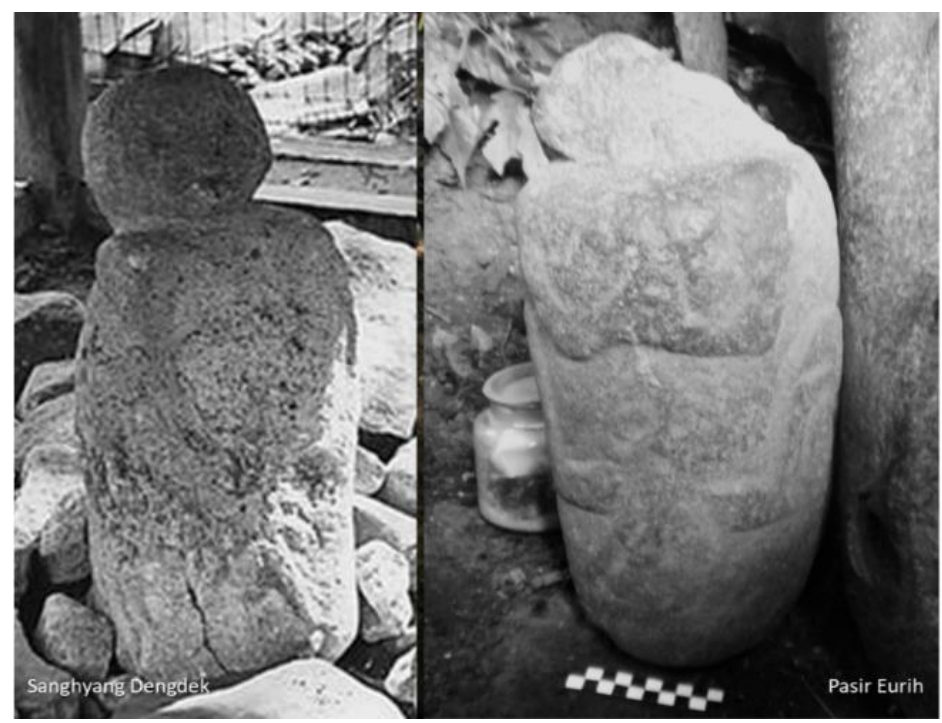

Figure 5. Anthropomorphic sculpture around the slope of Mount Pulosari (Souce: Guillot et al., 1996:

100, Fig 24; Fadillah, 2009)

Table 1. Pepper Plantation in Socio-Archaeological Context

\begin{tabular}{|c|c|c|c|}
\hline CLUSTER & SITES OBSERVED & $\begin{array}{l}\text { AGRO-ARCHAEOLOGICAL } \\
\text { ASSOCIATION }\end{array}$ & SOCIAL CONTEXT \\
\hline A & $\begin{array}{l}\text { Pabuaran } \\
\text { Ciomas } \\
\text { Sindangmandi } \\
300-500 \mathrm{M} \text { asl. } \\
\text { Slope of } 10-15 \%\end{array}$ & $\begin{array}{l}\text { Water springs, menhir } \\
\text { pepper, coffee, clove } \\
\text { rice field, horticulture }\end{array}$ & $\begin{array}{l}\text { Habitation, sacred } \\
\text { objects, } \\
\text { Sunda-Javanese hybrid } \\
\text { speakers }\end{array}$ \\
\hline B & $\begin{array}{l}\text { Baros } \\
\text { Pasir Peuteuy } \\
500-700 \mathrm{M} \text { asl. } \\
\text { Slope of } 10-15 \%\end{array}$ & $\begin{array}{l}\text { Water springs, menhir } \\
\text { pepper, coffee, clove } \\
\text { horticulture }\end{array}$ & $\begin{array}{l}\text { Habitation,Islamic } \\
\text { traditional school, sacred } \\
\text { place on pilgrimage, } \\
\text { Sundanese speakers }\end{array}$ \\
\hline $\mathrm{C}$ & $\begin{array}{l}\text { Mandalawangi } \\
\text { Pandat, Cihunjuran, } \\
\text { Nembol } \\
\text { Giripawana, } \\
\text { Sadahyang } \\
500-600 \text { m asl. } \\
\text { Slope of } 15-20 \%\end{array}$ & $\begin{array}{l}\text { Watersprings, megalithic } \\
\text { complex } \\
\text { Hindu-Buddhist relics, ceramic } \\
\text { and pottery shards, pepper, clove } \\
\text { and coffee plants, rice field and } \\
\text { horticulture }\end{array}$ & $\begin{array}{l}\text { Habitation, Islamic } \\
\text { boarding school, sacred } \\
\text { place on pilgrimage, } \\
\text { Sundanese Speakers }\end{array}$ \\
\hline $\mathrm{D}$ & $\begin{array}{l}\text { Sanghyangdengdek } \\
\text { Pasir Eurih } \\
\text { Mekarwangi } \\
400-500 \text { m asl. } \\
\text { Slope of } 15-20 \%\end{array}$ & $\begin{array}{l}\text { Watersprings, megalithic } \\
\text { complex, anthropomorphic } \\
\text { sculpture, local type Ganesha } \\
\text { relic, pepper, clove, coffee, rice } \\
\text { field and horticulture }\end{array}$ & $\begin{array}{l}\text { Habitation, Islamic } \\
\text { traditional school, sacred } \\
\text { object, Sundanese } \\
\text { speakers }\end{array}$ \\
\hline $\mathrm{E}$ & $\begin{array}{l}\text { Cibaliung } \\
\text { Cigeulis } \\
\text { Cimanggu } \\
300-400 \mathrm{~m} \text { asl. } \\
\text { Slope of } 5-10 \%\end{array}$ & $\begin{array}{l}\text { River flow, waterfall, prehistoric } \\
\text { surface finds, pepper, coffee, } \\
\text { clove, rice field and horticulture }\end{array}$ & $\begin{array}{l}\text { Habitation, bufferzone of } \\
\text { natural conservation, } \\
\text { Javan rhino habitat, } \\
\text { Sundanese speakers }\end{array}$ \\
\hline $\mathrm{F}$ & $\begin{array}{l}\text { Munjul, Ci Liman } \\
\text { Ci Danghyang } \\
100-300 \mathrm{~m} \text { asl. } \\
\text { Slope of } 0-5 \%\end{array}$ & $\begin{array}{l}\text { River flow, Sankrit inscription } \\
\text { pepper, coffee, clove, rice field } \\
\text { and horticulture }\end{array}$ & $\begin{array}{l}\text { Habitation, edu-tourism } \\
\text { object, Sundanese } \\
\text { speakers }\end{array}$ \\
\hline
\end{tabular}

Source: Processed from BPCB report (2020) and the author's observations in 2021. See Fig. 4 above).

Sindangmandi and Pasir Peuteuy on the slopes of Mount Karang and the villages of
Giripawana, Sadahiang, Pandat, Pasir Eurih, and Mekarwangi on the slopes of Mount 
Pulosari, with a slope of $5-20 \%$ and an ideal agro-climate, seems suitable for pepper cultivation (Table 1).

There are archaeological traces which are certainly not coincidental in the form of menhirs, dakon, mortars, stone altars (dolmen), and grinding stones, including anthropomorphic statues which the local community calls Sanghiang Dengdek, and other ancestral statues; made of andesite stone. This human depiction, when compared with similar findings at the Bada valley site, Central Sulawesi (Peter Bellwood (2017, pp. 285-6) and the Rampi hills, in north Luwu, South Sulawesi (Fakhri, 2016, pp. 30-34), is thought to date from the early metallic period, between 300-500 AD. All these archaeological traces are clues to early settlements before being influenced by Indian culture in the interior of Banten.

These are in the form of menhirs, dakon, mortars, stone altars (dolmen), and grinding stones; we here also include the anthropomorphic statues locally called Sanghiang Dengdek and other ancestor statues, most of which were made of white stone, and still awaits the attention of experts
(Figure 5). In 2021 residents of the southeast slopes of Mount Pulosari even found a type of local Ganesha (?) is associated with several of the springs that supply the river $\mathrm{Ci}$ Lemer which flows into the Sunda Strait (Figure 6).

By ignoring the prehistoric paradigm, this cultural ecosystem tends to become a surface 'archaeological assemblage'. Associative interpretation requires us to consider the economic perspective on the existence of the Tarumanegara inscription upstream of $\mathrm{Ci}$ Liman. The inscription text does indicate Purnawarman's efforts for hegemony in the farthest areas of his reign, but in this context, it is necessary to interpret the importance of resources as the reason for the conquest of the interior of the Sunda Strait. Insular Southeast Asian polities of the middle of the first Millennium AD there was a strong relation between religious ideology and efforts at increasing both trade and agricultural production (McKinnon et al., 1994), and for the area under discussion would associate such efforts with Tarumanagara and its position in the trade

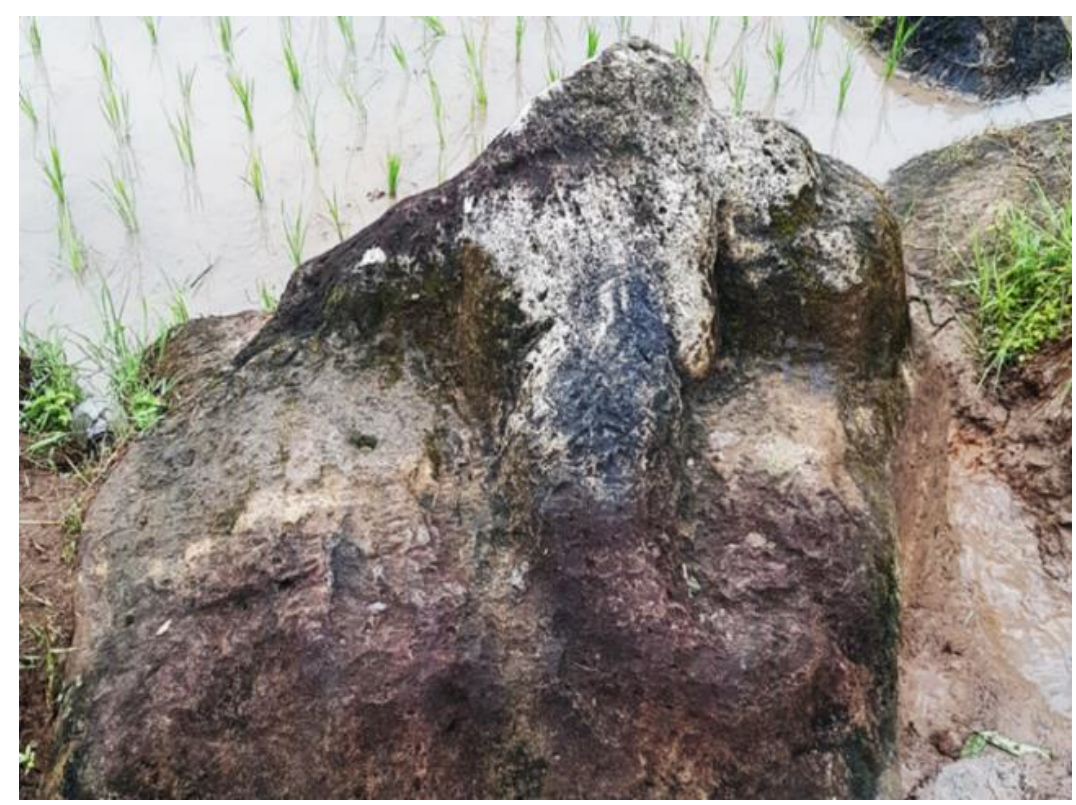

Figure 6. Local type Ganesha found by residents in Mekarwangi Village, Saketi, Pandeglang (Source: Fadillah, 2020) 


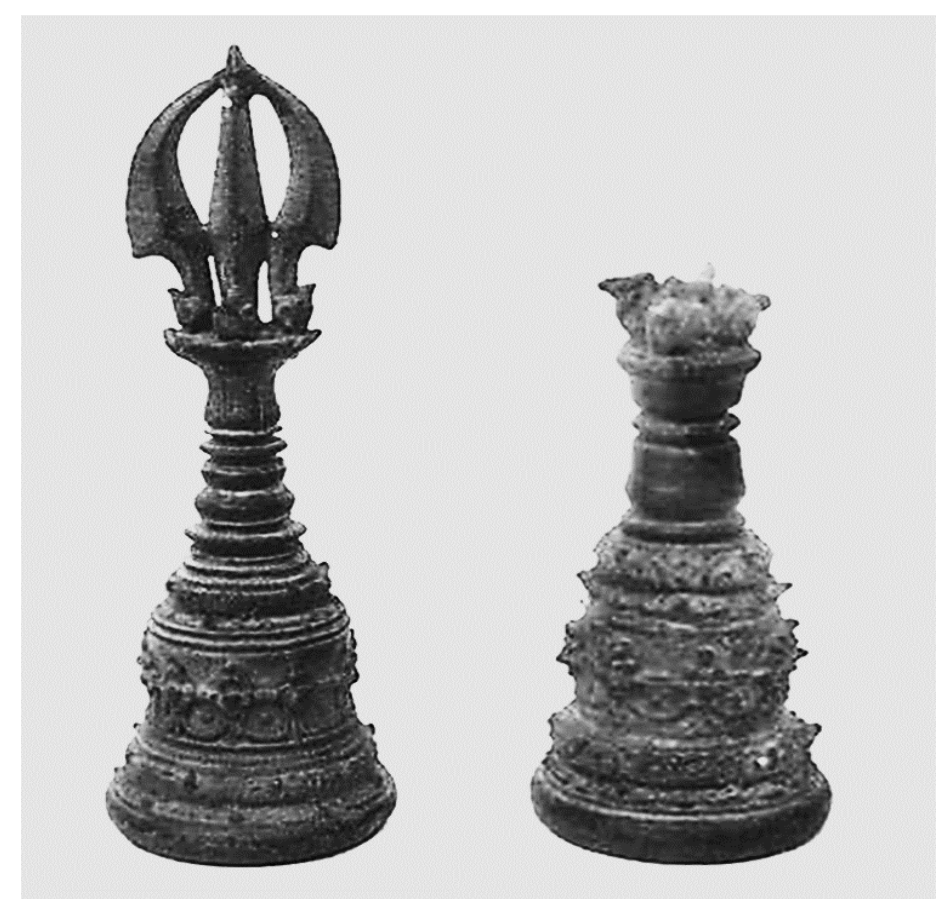

Figure 7. Genta from Pandat Village, Pandeglang (Source: Fadillah, 2001)

network between the Malacca Strait and the Java Sea (Wisseman-Christie 1995, pp. 254$55)$.

Both the BPCB survey team and our observations in several places in the valleys of the southern mountains and the lowlands that enter Serang, Pandeglang and Lebak noted pepper plants, along with other rhizome plants, especially in the Ci Liman network and the Ci Danghyang river area. On the pepper plantation route, which is managed by the inhabitants, there are many archaeological traces that are characterized by megalithic tradition and some HinduBuddhist relics, especially in the Mandalawangi area, Pandeglang Regency in the form of the foot of the statue at the Citaman site (see Fadillah, 2021, p. 208). These include a bronze ceremonial bell called genta pendeta at Pandat village which is thought to have originated from the $12^{\text {th }}$ to $14^{\text {th }}$ centuries, and thus would dated into the Banten Girang period (BPCB Team, 2020; Fadillah, 2001, pp. 201, 208; Juliadi et al., 2015, p. 63) (Figure $7 \& 8$ ). However, all of the 'prehistoric' or 'protohistoric' traces mentioned above are, a priori, not necessarily associated to the Banten Girang period of the $10^{\text {th }}$ and $15^{\text {th }}$ centuries. We therefore would propose the hypothesis that this megalithic legacy could be associated with ancient agricultural activities in general, and especially with: pepper cultivation and an upstream migration of people. This requires us to ask, is the historical landscape represented by topography, fertility, agro-climatic conditions, and traces of ancestral worship relevant to be aligned with the pepper growth phase around $400 \mathrm{AD}$ ? Interpretation in this direction will lead to two perspectives: economic base and religious background.

From an economic point of view, long before the establishment of a Banten Girang-centered 'Sunda Kingdom', there evidently were agricultural activities, supposedly centered around rice cultivation; given the suitability of land and climate, pepper could have been among the agricultural produce, to become a mainstay commodity in later centuries (cf. Boomgaard 2007, p. 192; Hall 2014, pp. 233-240). Meanwhile, from a socio-religious perspective (Heine-Geldern, 1942; Wheatley, 1983) the existence a megalithic tradition indicates well organized communities occupying the fertile land in 


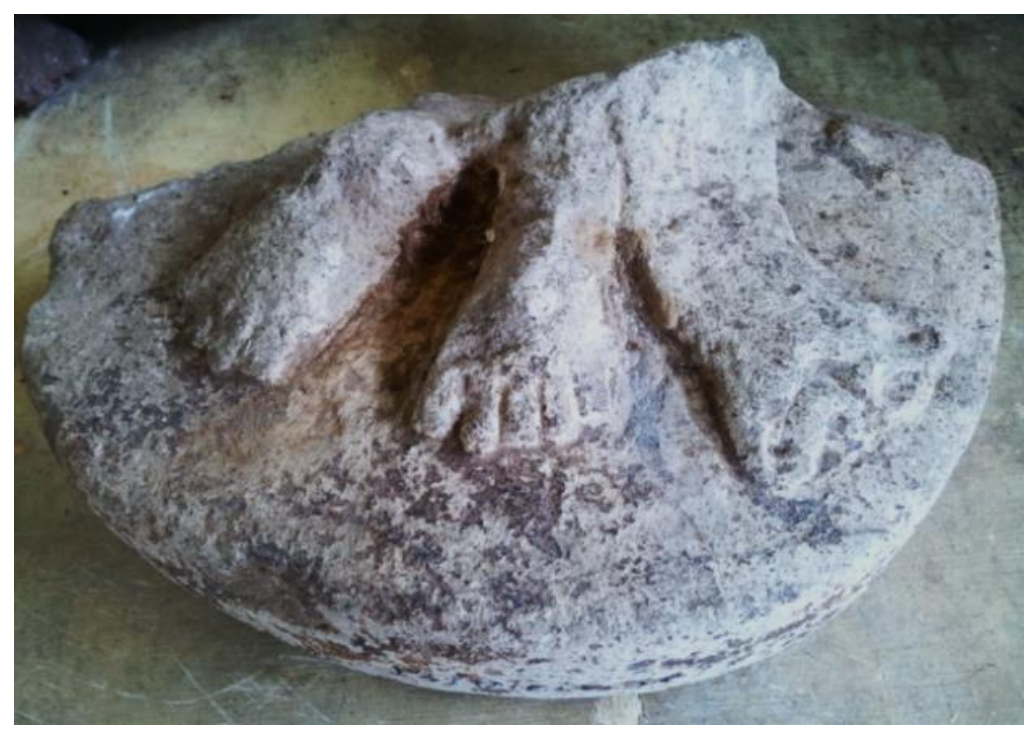

Figure 8. Fragment of a statue made of white stone at the Citaman site (Source Fadillah, 2021)

the interior, which, propsedly, came under increasing influence of Indic ideology, and thus a more centralized political fabric, in this case, as evidenced by the statues of Brahma, Shiva, Agastya, Durga, and Ganesha found on the slopes of Mount Pulosari, Shivasim (Guillot et al., 1996, p. 101). The megalithic tradition could also indicate that local beliefs strengthening social integrity in the interior for a sufficient time were not (or only superficially) influenced by religious elites in Banten Girang (Fadillah, 2001, pp. 54-59), who would have been the possible connective to and profiteers of a trade-in pepper.

Such a difference in trust and social status does not necessarily hamper economic relations between upstream and downstream. Still, in later times, rural and urban communities of different religious orientations appear to have been able to make regular contact in the 'spirit' of the pepper trade or other spice. From various European testimonies, before 1609, Banten was a free market that complied with the law of supply and demand. The buyers went directly to wholesalers to stockpile pepper. It was they, especially the Chinese, who went to look for these spices in the interior of Banten. The Islamic government almost acts as an arbiter to settle any disputes that may arise between the traders (Guillot, 1992, p. 67).

This cross-cultural economic exchange continued into the $20^{\text {th }}$ century as happened in Kanekes village, Lebak Regency. The Baduy community in Lebak, for example, adherents of animism living in closed villages, always exchanging their garden produce for clothes and food from the market provided by Islamic traders, even though they still adhere to closed customs (Berthe, 1965, p. 191).

\section{Pepper: political regime}

Archaeological research at the Banten Girang site provides evidence of a well-developed export trade in Banten. The material evidence from excavations not only confirms Portuguese documents from the early $16^{\text {th }}$ century, but provides strong clues that the spice trade dates back centuries. The main basis for this hypothesis rests first on the discovery of imported ceramic shards which reached more than 10,075 pieces in an area less than half of the Old Banten site in the $17^{\text {th }}$ century (Guillot et al., 1996).

This archaeological fact offers two interpretations. First, the discovery of ceramic shards mostly came from China, and 
a small part from Thailand and Vietnam. However, since the highest fragment of the relative chronological chart is shown by Chinese ceramics from the Song and Yuan periods, Banten Girang's intensive contact with the outside world occurred in the $14^{\text {th }}$ century. This interpretation refers to the formation and role of Banten Girang's political economy since the $10^{\text {th }}$ century and reached its peak in the $13^{\text {th }}$ and $14^{\text {th }}$ centuries, before declining in the $15^{\text {th }}$ century and ending in the early $16^{\text {th }}$ century.

The discovery of ceramic fragments is also confirmed by other archaeological evidence dating from the same period. Hindu relics in Karangantu, the secondary port of Banten, in particular a statue of Nandi (Juliadi et al., 2015, pp. 63), as well as Song and Yuan trade ceramics on the Banten Lama site, show that the Ci Banten estuary already served as a port of a Pre-Islamic Kingdom. This interpretation is related to the Banten-Chinese axis which may have existed since the $10^{\text {th }}$ and $11^{\text {th }}$ centuries. Trade traces are provided by Yue-ware ceramics although in small proportions (Guillot et al., 1996, pp. 148-49).

However, the early stages of bilateral relations are still difficult to reconstruct. A large number of ceramic shards mostly produced in Guangdong and Fujian and over the next two centuries were found at the Banten Lama site. The ceramic wares, as noted by Chau Ju-kua, were shipped via Quanzhou; the biggest port in Fujian. Chau Ju-kua also provides one of the oldest mentions of Banten in Chinese literature, noting that at least some of the pepper imports originated from the port of Banten, which he called Sin-t'o (Hirth \& Rockhill, 1911 , p. 222). So there is no doubt that this spice is what the Chinese in Banten are most looking for (Guillot et al., 1996, pp. 121-22).

Our second premise of a Banten-India axis, is underlined by the Indian iconographic evidence, and especially so the Shiva statue group, and would be closely related to the Banten Girang site and polity.
However, instead of explaining Banten Girang's relationship with India, this indication actually points to the 'diaspora' of a Hindu-Javanese elite to Banten Girang (Guillot et al., 1996).

We assume that the Indian textile trade in the $17^{\text {th }}$ century (Boontharm 2003: 350; Rantoandro, 1995, p. 32) may shed light on the earlier period. Apart from spinning wheels and other looms found at the Banten Girang site, not much remains: it is difficult to find traces of organic objects such as cloth (or, in our case, pepper). However, hypotheses must continue to be formulated; this means that it is possible for Indian traders or priests to be present in Banten Girang even though the Hindu statues from Mount Pulosari do not directly refer to a direct relationship with India (Guillot et al., 1996, pp. 102-5, Photo 44-49).

In connection with the Banten-India relationship, Indian merchant groups, especially those from southern India, had played an important role in government positions in the Islamic Banten era before this role was replaced by Chinese merchants (Hall, 2014, pp. 232-33; Lodewycksz, 1915, pp. 139-156; Rantoandro, 1995, pp. 25-39), and could be an analogy for the presence of Indian traders since the Banten Girang era. Some of the glass beads found at the Girang Banten site are said to have come from West Asia (Adhyatman, 1996, p. 224), most likely imported by traders from South Asia and possibly mainland Southeast Asia since the early $5^{\text {th }}$ century AD.

The association of jar graves, Dongson-specific bronze objects, megalithic remains and Indian beads at several coastal sites north and west of Banten (Heekeren, 1956; Indraningsih, 1986) recalls Wisseman Christie's suggestion:

"The same burials contain numerous glass and stone beads from south and east India. These graves also appear to mark an important stage in the elaboration of a number of localized but interrelated 'megalithic' traditions, the main features of 


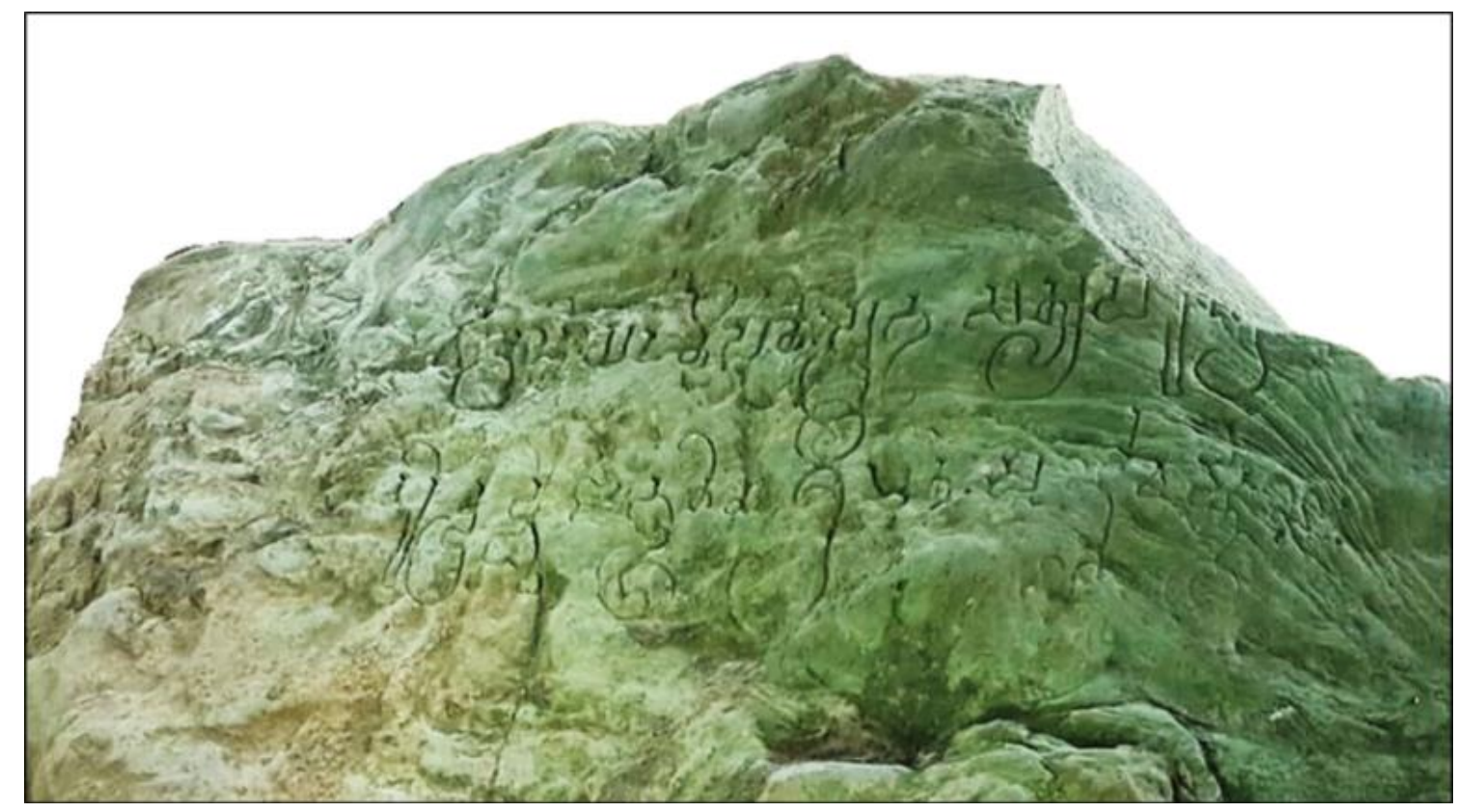

Figure 9. Stone inscription of Purnavarman on the river bank of Ci Danghyang, Pandeglang

(Source: Fadillah, 2021)

which were stone slab graves, dolmens, standing stones, stone circles, stone pavements, stone terraces, and so forth. Foci of these traditions are located in south and west Sumatra, north and west Java, Bali as well as parts of Borneo and some eastern island" (Wisseman-Christie 1995: 246).

From this assumption, the possibility of Indian influence only appeared in Banten in the $10^{\text {th }}$ century $\mathrm{AD}$, whereas five centuries earlier Purnawarman had reached the peak of his glory in West Java as stated in the Tugu Inscription, near Jakarta (Figure 4). River works may be related to irrigation works as originally thought (Coedès, 1964) but canals are primarily to prevent flooding around the city (Noorduyn, J. \& Verstappen, 1972, pp. 298-307; Wisseman-Christie 1995, pp. 257-58). In this context, Hermann Kulke's interpretation can be attributed to the presence of his inscription in Banten Selatan, which focuses on introducing the concept of 'State' or 'city center' from which the ruler controlled conquered territories (Kulke, 1989, pp. 6 - 7).

The remotest and isolated area of Tarumanagara 'it is not clear whether real or nominal' is evidenced by the placement of an inscription at $\mathrm{Ci}$ Danghyang, inland south of
Banten (Figure 9). Written in Pallawa and Sanskrit script, the inscription states: "vikranto 'yam vanipateh prabhuh satyapara (k) ra (mah) narendraddvajabhutena srimatah purnna-varmmanah" means: This is [a sign] of true valor, majesty, and courage from the king of the world, the venerable Purnavarman, the banner of all kings (Damais, 1967, pp. 687 8).

The only convenient route to reach $\mathrm{Ci}$ Danghyang is the north coast and the east side of the Sunda Strait, thus, hypothetically, encompassing Banten Girang. A possible motive for claiming hegemony over these areas could have been control over their produce.

Given Punavarman's interest in hydraulic constructions (and thus, in all possibility, wet-rice farming) at the very center of his reign its would seem farfetched if a remote hinterland would be claimed for mere staple food items, but should have been tied to commodities more important than rice (cf. Boomgaard, 2007, p. 191). We know from Chinese sources, that Tarumanagara several times sent envoys to China (Pelliot, 1904, p. 284), and would 


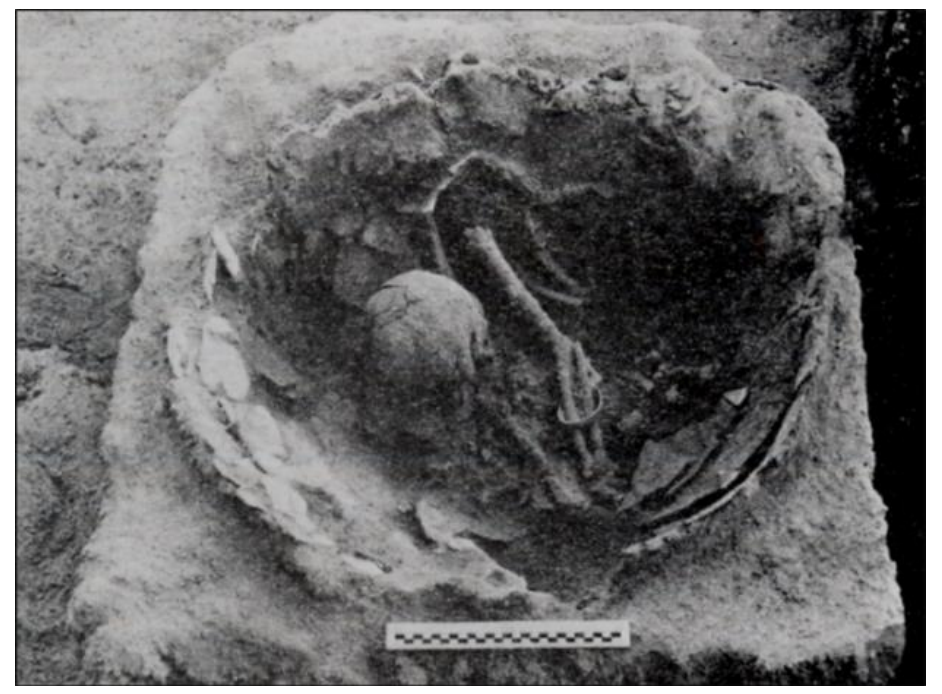

Figure 10. Human skeleton and funeral gifts in earthenware at Anyer Lor site (Source: van Heekeren, 1956).

propose that the envoys brought exotic objects to be presented to the Chinese emperor, some of which would have came from the conquered areas; the interior of Banten was one of them.

However, there are still difficulties in understanding the economic basis of the Hindu colony in Banten by the $5^{\text {th }}$ century $\mathrm{AD}$, apart from making water channels around the river estuary -as was once made around the capital city of Banten Girang five centuries later-we are missing detailed information on related developments. Therefore, the suggestion of Dalsheimer and Manguin (1998) and also Wisseman Christie (1995) inspired us to build a foundation of thought.

This argument is important to see the relationship between Vaishnava followers and the aristocratic ethos through political power. This passion enabled them to establish a commercial base in West Java in the early fifth century. The commercial nature of the Vishnu followers seems to give us an opportunity to show that they played an active role in trade networks in Southeast Asia as did Buddhists before (Dalsheimer \& Manguin, 1998, pp. 108-109). The Vaisnava ruling group, although insignificant in Indonesia, would have survived into the seventh century, before losing influence under the domination of the Srivijaya Buddhist kingdom

The thinking of these scholars allows us to speculate for a correlation with a vague period in Banten's early history between the $5^{\text {th }}$ and $10^{\text {th }}$ centuries. The commercial character of Vishnu's followers may be related to the early exploitation of pepper in the interior of Banten. In a period of five hundred years of uncertainty, there were at least two trading dynasties that controlled the waters of the Sunda Strait: after Tarumanegara declined in the second half of the $7^{\text {th }}$ century, Srivijaya then replaced it until the $10^{\text {th }}$ century as stated in the Kebonkopi II Inscription (Bosch, 1941; Guillot et al., 1996, p. 111).

This interpretation has the consequence of proving whether the pepper trade was at an early stage under Tarumanegara's political control before it actually developed in the Banten Girang era. But this invites ambiguity; because the state in Shiva style is usually based on agriculture. On the other hand, in this case Banten Girang relies on trade, is it possible that Banten Girang will inherit the spirit of the trading nation Vishnu and Buddha even though the elites are more inclined to Shiva? 


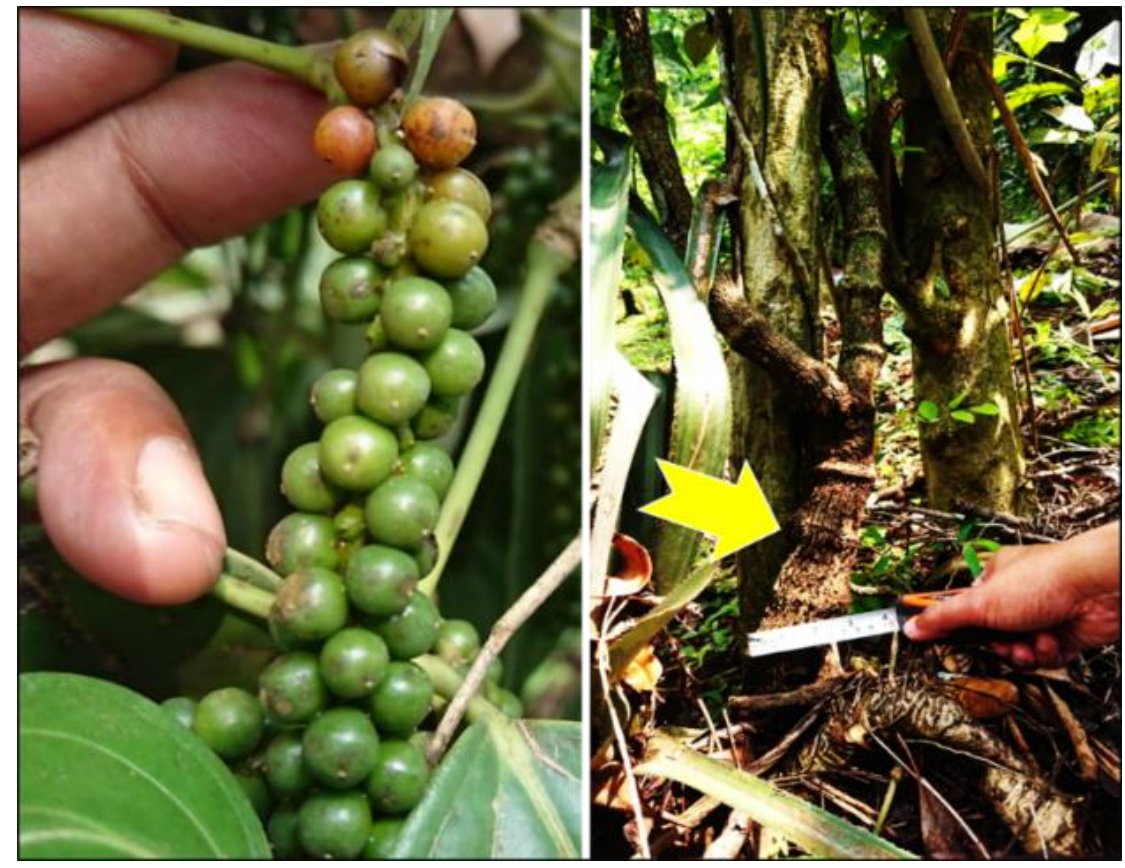

Figure 11. Papper plant around Cibaliung, Pandeglang (Source: BPCB Team, 2020)

Another fact that may not be directly related to this commercial economic phenomenon is the discovery of human skeletons in jars (pottery for graves) on the west coast of Banten, in the village of Anyer Lor. Often associated with similar graves on Gilimanuk, the west coast of the island of Bali (Soegondho, 1985, pp. 46-53), as well as other sites in the Indo-Malaysian archipelago ((Bulbeck, 2017, pp. 147-152), this archaeological evidence deserves attention (Figure 10).

It is true that the findings refer to protohistoric traces, but Heekeren's conjecture dates back to about 300-400 AD (van Heekeren, 1956). Further research has uncovered objects that were most likely imported from elsewhere such as: earthenware, beads, and metal (Sukendar et al., 1982, pp. 23-24). In terms of age, if this assumption can be proven, the findings are not far from the Purnavarman inscription. The spatial and temporal dimensions suggest that before Purnavarman placed the inscription, terminus antequem it appears to have existed another communities on the same coastline: Anyer Lor in the north and the Cidanghyang inscription in the south coast. We know that until recently even small fishermen were accustomed to navigating this route in just a few hours.

The discovery of the pottery burial site and the Purnawarman inscription could be able to fill the puzzle of the early history of trade in Banten. Historical events can begin in the early centuries $\mathrm{AD}$, considering that Indian pottery was also found at the Buni site (Walker \& Sughondo, 1977), the north coast of West Java, the Sunda Strait is not an 'foreign route' for religious adventures. Statues of Shiva and Ganesha found on Panaitan Island, possibly from the $12^{\text {th }}$ or $14^{\text {th }}$ century, can prove that this route remained important until the Girang Banten period.

It is not surprising that several political regimes played a significant role in the region. In this regard, economic resources must be the main reason: exotic forest products such as agarwood and other resin trees can still be found in Carita conservation forest park (Taman Hutan Raya Carita) and other places in the interior of Ujung Kulon National Park, including 
Javan rhino horn that have been found during the excavation of Banten Girang (Due Awe, 1996, pp. 209-210). We suspect that Purnawarman's conquest to the coast of the Sunda Strait was not purely religious in nature.

\section{Any traces of pepper at the archaeological site?}

In a commercial system there are interrelated factors between two or more parties interacting at a market. In the present case, Banten's pepper trade, our first question should be directed at the source that supplied the spice. Banten and its ports would have been the 'first' market, situated at a downstream location that functioned as a place of redistribution of the spice into a wider 'international' economic network. There should have been a chain of exchange systems between the upstream production activities and the market and port site. To ensure the smooth running of activities, this interaction would have invited intervention from political forces, and eventually become an entry point for new ideologies and organizational possibilities (cf. Bronson, 1977; Kathirithamby-Wells, 1993).

For our topic, a telling example from the $16^{\text {th }}$ century could be seen from the contents of the Portuguese and Sundanese agreements at the end of the Banten Girang period which were mainly aimed at improving trade relations. To ensure the implementation of this cooperation, there was a clause stating the need to build a fort to protect the interests of Portuguese traders in the area. The Sunda kingdom allowed the Portuguese to build forts outside the capital and even guaranteed that the Portuguese would get as much pepper as they wanted (Guillot, 1991, p. 54). The Portuguese source clearly mark the Banten Girang site as the capital of the Kingdom of Sunda, the guardian of the route to the upstream pepper production areas, and its influence is also proven by the existence of natural fortresses, various artifacts and monuments that still exist today in the upper reaches of the $\mathrm{Ci}$ Banten.

The Archaeological records indicate that the pre-Islamic polity passed through a long period of time, and shows tidal cycles between the $10^{\text {th }}$ and $16^{\text {th }}$ centuries. Eventually, Banten Girang had established a transoceanic commercial relationship through the mouth of $\mathrm{Ci}$ Banten. When the political power and ideology changed for an Islamic dynasty, the pepper trade still continued until the kingdom finally fell under Dutch rule centered at neighboring Batavia, the very site of Purnavarman's best documented undertakings (cf. Henley, 2015, p. 163; Ueda et al., 2016, p. 90).

As it is difficult to find direct evidence of pepper at archaeological sites in, e.g., pollen samples or phytoliths, the close relationship between political power and trading activities should be considered to uncover the origins of pepper cultivation in the interior of Banten. Unfortunately, at that time (1990-1992) the archaeologists may not have considered the need for physical evidence of pepper as an organic material, which is certainly much less than findings of earthenware, ceramics, glass and beads in archaeological excavation.

In connection with these traces of pepper, excavations in Pandat Village, Mandalawangi District, Pandeglang, carried out by the Indonesian Research Center for Archaeology, have provided several insights. The discovery of stone tools for grinding or pounding and broken ceramics dates back to the $14^{\text {th }}$ century (Wibisono et al., 2016) complementing the discovery of a stone pounder at the Bangangah site, near Pandat (Fadillah, 2001, p. 61). But unfortunately, this study has not found any traces of pepper in archaeological assemblages, especially in the cultural layer. It can be interpreted that stone tools cannot be associated with pepper planting activities.

Archaeological evidence in the interior of Banten such as megalithic remains related to Indian religious traces 
does require a cosmological approach that has been proposed by, e.g., Heine-Geldern model (1942) still and often referred to in reconstructing the establishment of the early Southeast Asian states. In this regard, however, we also would consider Karl Polanyi's substantive economic model as elaborated by Wheatley (1975), which focuses on ancient exchange patterns, and the subsequent changes various aspects of redistribution and trade under the control of political power. Responding to the ideas of Wheatley, Wisseman Christie's suggestion of the need for research on economic geography and anthropology is indeed important to gain an understanding of traditional rural population in the case of ancient pepper plantations, however, we also need consider another approach (WissemanChristie, 1995)

Based on their content of calories and other substances, the pepper plants and their various varieties known today are theoretically identical to the commodity traded in Banten in the $10^{\text {th }}-17^{\text {th }}$ century (Figure 11). The plant grows in two places: we mentioned the isnterior of Banten above; and should add the expansion of pepper plantaions into the lowlands of South Sumatra under Banten's political control.

From several sources it is known that pepper has been found in Egypt since the $2^{\text {nd }}$ millennium $\mathrm{BC}$, but whether the $16^{\text {th }}$ century pepper is the same species as the pepper found as a fragrance or preservative in the body of King Ramses II around 1200 BC (see Fuller et al., 2011, pp. 544-58). We also don't know when south Indian pepper started to be cultivated or just collected in the forest.

The results of paleo-botanical analysis assure us that pepper is an endemic plant of the wet forests of South India that was transferred to the coast before being distributed to civilization centers on the Nile Valley via the Arabian Sea and the east coast of Africa (Gilboa \& Namdar 1915, pp. 272). These findings could be important for similar research in the Malay Archipelago, but unfortunately, we are still lacking comparable knowledge about the pepper plant in Southeast Asia. Even though geographic and agro-climatic conditions would allow the pepper plant to grow in Southeast Asia, including the Indonesian archipelago, we do not know whether it developed from a local wild plant or was deliberately cultivated en masse in the context of pepper monoculture. While various historical sources and field data actually reveal many issues about pepper it turns out that more questions arise than the answers given.

The presently available data undoubtedly Banten as an important source for black pepper in the $14^{\text {th }}$ and $17^{\text {th }}$ centuries, with the Indian Pipernigrum $L$ variety cultivated in its interior. Cultivation of pepper in India probably only started about 2000 years ago, following a sufficiently long time of mere collecting from forests. It has been considered that pepper only than was distributed into the Indo-Malaysian archipelago, and from there to other pepper-producing areas (Hao et al., 2012, pp. 296). This least proposes that since some time in the $1^{\text {st }}$ Millennium AD, the Indian Ocean has been open to a wide trading network.

The extent of the involvement of Southeast Asia in the spice trade of these times could not be ascertained. Given what we know about the volume of production along the Malabar coast (see, e.g., Bulbeck et al., 1998 and the sources there mentioned), Banten pepper production almost probably was not aimed at Indian consumers, instead, 'Indonesian' pepper was exported to China through the political powers that had been established on the north coast of Java - Zhao Rugua (in Hirth and Rockhill, Transl., Ed., 1911, p. 222) mentions a number of 'places in Sho-p'o [Java]: Su-ki-tan, Ta-pan, Pai-hua-yiian, Ma-tung, and Jung-ya-lu' that export pepper to China, but notes that the variety 'coming from Sin-t'o [Sunda] is the best'. 
The question then is, what could have been the role of Tarumanagara in this early phase of the spice trade? We firmly believe that the expansion of its influence to almost the entire interior of West Java must be understood from an economic point of view, and a pepper-driven one at that.

It is possible that Banten's first Hindu kingdom became a pioneer in the overseas spice trade, in addition to establishing relations with China by sending official envoys (Moens, 1937); while the archaeological traces of Indisan ideology denote religious-cultural relations with South Asia. It has even been argued that the very name 'Tarumanagara' could have originated from the word Tarumapuram (?), a toponym found in South India, one of which is located at Cape Comorin (Moens 1940, pp. 96-7; Wessing, 2011, pp. 328-29).

\section{Spice trade cycle in Banten area}

At the end of this review, there are still many open questions, while the material evidence is still a historical puzzle. However, in the pepper exchange system, there is a driving force to gain, even if possible, control over the resource area. Then for economic reasons, there is a tendency to realize long-distance adventures, whatever the motivation, it is possible for groups of small traders to enter transactions at ports and even upstream (Fuller et al., 2011, p. 555).

However, the historical cycle still applies; it rises and develops, and then, often enough, experiences a downward phase. Likewise in the pepper trade; we watched the maritime history orchestra in the archipelago. Aceh, Banten, as well as Banjarmasin in South Kalimantan are good examples, which are still remembered as the largest port of pepper in the $17^{\text {th }}$ centuries after which it faded under the influence of Europe's economic powers (Boontharm, 2003, p. 46; Hall, 2014, pp. 353-54). The pepper monopoly changed hands to the VOC which until the early $19^{\text {th }}$ century still used the charisma of local government to control the pepper trading system in its territory.

Former plantations and traditions of pepper cultivation on the slopes of Mount Karang, Aseupan and Pulosari, and also in the interior of the Sunda Strait near the slopes of the Kendeng mountains, are testimony that may have occurred since the beginning of the $1^{\text {st }}$ millennium. Plantation areas, transportation routes, redistribution, and ports of pepper are a separate note in the history of pepper development in Banten.

The pepper cultivation has become part of the historical cycle of political economy in the waters north and west of Banten. This cycle is a link in the history of longue durée (cf Braudel, 1960) where the historical phases alternate until the entry of industrial crops: coffee, tea, cloves, tobacco, and rubber, marking the start of a liberal economic system in the interior of Banten, as experienced by almost all Dutch colony in the archipelago.

Pepper plants are no longer the main source of livelihood. As a result, it is also unable to improve the welfare of farmers. The name Teluk Lada at the mouth of the $\mathrm{Ci}$ Liman river may be the ancient port of Panimbang on the west side of the Sunda Strait, but evidence of its trading activities must be sought further upstream; where Purnavarman erected the inscription in the second half of the $5^{\text {th }}$ century AD.

However, we still hope that in the future there will be systematic research on the issue of the ancient pepper trade. We know that the contribution of archaeological research over the last five decades at the sites of Banten Lama and Banten Girang has been able to reconstruct the history of trade on the north coast of Banten.

\section{CONCLUSION}

The historical schema of pepper on the north coast of Java shows a long phase of Southeast Asian maritime trade linking South Asia and East Asia. Old Javanese textual sources have led historians to 
determine the beginning of the exchange that began in the $9^{\text {th }}$ century and increased in the $11^{\text {th }}$ century AD, especially with East Java ports.

At the same time, on the northern coast of West Java, a trade government was established which, based on archaeological evidence, had established trade relations with China and India. The progress of the pepper trade in the $16^{\text {th }}$ and $17^{\text {th }}$ centuries was probably spearheaded by pre-Islamic rulers who were founded in the $10^{\text {th }}$ century at the site of Banten Girang.

The importance of pepper to the economy of Banten is demonstrated by the existence of an old plantation area in the interior of Banten which can be accessed both by river and land from the main $\mathrm{Ci}$ Banten river and also from the strait of Sunda. Several archaeological remains associated with fertile areas can be an important indicator in tracing the early history of pepper.

At least preliminary evidence can reveal three important clues. First, Banten's maritime economy relies heavily on pepper as its main export commodity in exchange for ceramics, beads, and possibly metal goods from other ports. Second, Banten which is located in the territory of the Tarumanegara kingdom in the $5^{\text {th }}-7^{\text {th }}$ century, as shown by Sanskrit inscriptions and later Hindu statues, is probably the earliest country to introduce pepper to the Banten area as an important crop. And third, considering pepper is a plant originating from India, the possibility of Indian contact with the coastal area of Banten has occurred earlier than Tarumanegara, although a direct relationship with Tarumanegara is still difficult to prove.

\section{Acknowledgments}

My high appreciation goes to Juliadi, Aditya, Memed, Nurjaya (BPCB Banten), Budi Prakosa and Samsu Bahri (Banten Heritage Institute), Firman Gempur Amir (Banten Tourism Guides Association), Syahrul and Tasmen (History Education Students of Untirta), Rohili (Pasir Eurih village) for all information on archaeological sites as well as pepper cultivation at the observation sites. Appreciation was also given to Dr. Ian Caldwell for reading the draft of this paper.

\section{REFERENCES}

Adhyatman, S. (1996). "Manik-manik", in C. Guillot, L. Nurhakim, S. Wibisono, Banten Sebelum Zama Islam, Kajian Arkeologi Di Banten Girang 932? - 1526 (1996), Jakarta: Pusat Penelitian Arkeologi Nasional, pp. 217-225.

Ambary, H. M. (1977). "A Preliminary Report of the Excavation on the Urban Sites in Banten (West Java)." Bulletin of the Research Centre of Archaeology of Indonesia 11.

Bellwood, P. (2017). First Islanders: Prehistory and Human Migration in Island Southeast Asia, Hoboken, New Jersey: Wiley Blackwell.

Berthe, L. (1965). Aînés et Cadets, l'alliance et la hiérarchie chez les Baduy (Java Occidental), L'Homme, Etudes sur la parente, Tome 5 (3-4), pp: 189-223. https://doi.org/10.3406/hom.1965.366748

Boomgaard, P. (2007). "From Riches to Rags? Rice Production and Trade in Asia, Particularly Indonesia, 1500-1950." Pp. 185-99 in A History of Natural Resources in Asia. New York: Palgrave Macmillan. 
Boontharm, D. (2003). The Sultanate of Banten AD 1750-1808: A Social and Cultural History .London, Hull University.

Bosch, F. D. K. (1941). "Een Maleische Inscriptie in Het Buitenzorgsche.” B.K.I 100:49-53.

BPCB Team. 2020. Laporan Pengembangan Atribut Jalur Rempah Simpul Banten. Serang, Banten.

Braudel, F. (1960). "History and the Social Sciences: The Long Duration." American Behavioural Scientist 3:3-13.

Breugel, J. de R. van. (1856). "Bedenkingen over Den Staat van Bantam.” Bijdragen Lot de Taal-, LandEn Volkenkunde (BKI) Nieuwe vol:110-69.

Bronson, B. (1977). "Exhange at the Upstream and Downstream Ends: Notes toward a Functional Model of the Coastal State in Southeast Asia." Pp. 38-52 in Economic exchange and social interaction in Southeast Asia, edited by K. L.Hutterer. The University of Michigan.

Bulbeck, D. (2017). "Traditions of Jars as Mortuary Containers in the Indo-Malaysian Archipelago." Pp. 141-59 in New Perspectives in Southeast Asian and Pacific Prehistory, The Archaeology of Sulawesi: A Strategic Island for Understanding Modern Human Colonization and interactions across our Region. Canberra: Australian National University.

Coedès, G. (1964). Les Etats Hindouisés d'Indochine et d'Indonésie. Paris: Editions Boccard.

Cortesao, C. (1944). The Suma Oriental of Tome Pires. London: Hakluyt Society.

Dalsheimer, N., Manguin, P. (1998). "Visnu Mitrés et Réseaux Marchands En Asie Du Sud-Est: Nouvelles Données Archéologiques Sur Le Ier Millénaire Apr. J.-C.” BEFEO Tome 85:87-123.

Damais, LC. (1967). "Une Publication Récente Du Service Archéologique de 1'Indonésie." Befeo 53:685-94.

Djajadinigrat, H. (1983). Tinjauan Kritis Tentang Sajarah Banten, Sumbangan Bagi Pengenalan SifatSifat Penulisan Jawa. Jakarta: Djambatan.

Due A, R. (1996). "Hewan", in C. Guillot, L. Nurhakim, S. Wibisono, Banten Sebelum Zama Islam, Kajian Arkeologi Di Banten Girang 932? - 1526 (1996), Jakarta: Pusat Penelitian Arkeologi Nasional, pp. 209-211.

Fadillah, M. A. 2001. "Mitos 'Gunung Suci' Di Pandeglang, Banten: Sebuah Kontemplasi Arkeologis." Pp. 49-69 in Manusia dan Lingkungan, Keberagaman Budaya dalam Kajian Arkeologi, edited by Tony Djubiantono \& Moh Ali Fadillah. Bandung: Ikatan Ahli Arkeologi Indonesia.

Fakhri. 2016. "Situs Rampi: Masa persebaran arca batu dan hubungannya dengan di wilayah situs terdekat", Walennae 14 (10):23-36.

Fuller, D. Q., Nicole N. B, Tom H, \& Robin A. (2011). "Across the Indian Ocean: The Prehistoric Movement of Plants and Animals." Antiquity 85:544-58.

Gilboa, A, \& Dvory N. (1915). "On the Beginnings of South Asian Spice Trade with the Mediterranean Region: A Review.” Radiocarbon 57 (2):265-83. doi: DOI: 10.2458/azu_rc.57.18562.

Guillot, C. (1989). "Banten En 1678." Archipel 37:119-51.

Guillot, C. (1991). "La Nécessaire Relecture de l'accord Luso-Soundanais de 1522.” Archipel 42:5376.

Guillot, C. (1992). "Libre Entreprise Contre Économie Dirigée : Guerres Civiles à Banten, 1580-1609.” Archipel 43:57-72.

Guillot, C., Hasan M. A., \& Jacques D. (1990). The Sultanat of Banten. Jakarta: Gramedia Pustaka Utama.

Guillot, C., Lukman N., and Sonny C. W. (1996). Banten Sebelum Zama Islam, Kajian Arkeologi Di Banten Girang 932? - 1526. Jakarta: Pusat Penelitian Arkeologi Nasional.

Hall, K. R. (2014). "European Southeast Asia Encounters with Islamic Expansionism, circa 1500-1700: 
Comparative Case Studies of Banten, Ayutthaya, and Banjarmasin in the Wider Indian Ocean Context." Journal of World History 25 (2-3):229-62.

Hao, C., Rui F., Milton C R., Le-he T., Hua-song W., Jian-feng Y., Zheng W. \& Yu H. (2012). "Modeling the Potential Geographic Distribution of Black Pepper (Piper Nigrum) in Asia Using GIS Tools." Journal of Integrative Agriculture 11 (4):593-99.

Harkantiningsih, N. (2013). "Ceramics along the Spice Trade Route in the Indonesian Archipelago in the 16th-19th Century." Forum Arkeologi 26 (1):29-37.

Hazeu, G. A. J. (1905). "Een Beschreven Koperen Plaat Uit de Lampongs.” TBG 48:1-12.

van Heekeren, H. R. (1956). "Note on a Proto-Historic Urn-Burial Site at Anjar, Java." Anthropos 51(1/2):194-200.

Heine-Geldern, R. (1942). "Conceptions of State and Kingship in Southeast Asia." The Far Eastern Quarterly 2:15-30.

Henley, D. (2015). "Ages of Commerce in Southeast Asian History." Verhandelingen van Het Koninklijk Instituut Voor Taal-, Land- En Volkenkunde 300(Environment, Trade and Society in Southeast Asia A Longue Durée Perspective (Eds: David Henley and Henk Schulte Nordholt)):120-32.

Hirth, F dan W. W. Rockhill. (1911). CHAU JU-KUA: His Work on the Chinese and Arab Trade in the twelfth and thirteenth Centuries, entitled Chu-fan-chi. St. Petersburg: Imperial Academy of Sciences

Indraningsih, J. R. (1986). "Pemukiman Prasejarah di sepanjang daerah aliran Sungai Cibanten hilir: Sebuah kajian awal", Pertemuan Ilmiah Arkeologi, V-IIa Aspek Sosial Budaya, Jakarta: Pusat Penelitian Arkeologi Nasional.

Juliadi, Sonny P. W., Bayu A., Pahlawan P. S. N., \& Mimi L. (2015). Ragam Pusaka Budaya Banten. Kedua. Serang-Banten: Dinas Kebudayaan dan Pariwisata Provinsi Banten dan Balai Pelestarian Cagar Budaya.

Kathirithamby-Wells, J. (1993). "Hulu-Hilir Unity and Conflict: Malay Statecraft in East Sumatra before the Mid-Nineteenth Century." Archipel 45:77-96. doi: doi : https://doi.org/10.3406/arch.1993.2894.

Kennet R. H., (2010). "Multi-dimensional Networking: Fifteenth-Century Indian Ocean Maritim Diaspora in Southeast Asian Perspective, in Journal of the Economic and Social History of the Orient, JESHO 49 (4) January 2010: 454-481.

Kristofery, L., Murtilaksono, Kukuh, Dwi P. T. B. (2019)., "Simulasi Perubahan Penggunaan Lahan Terhadap Karakter Hidrlologi Daerah Aliran Sungai Ciliman”, Jurnal Ilmu Tanah dan Lingkungan, 21 (2) Oktober 2019: 66-71 (69-70).

Kulke, H. (1989). "Epigraphical References to the City and the State in Early Indonesia." in Panel on early Indonesian state formation during the Association for Asian Studies Meeting. Washington DC.

Lodewycksz, W. (1915). “D'eerste Boek: Historie van Indien Vaer Inne Verhaelt Is de Avontueren Die Hollandtsche Schepen Bejeghent Zijn.” Pp. 139-156 in De eerste schipvaart der Nederlanders naar Oost-Indie onder Cornelis de Houtman, 1595-1597, edited by G. P. Rouffaer G.P and J. Ijzerman. The Hague: Nijhoff for Linschoten-Vereeniging.

Lombard, D. (1970). "Pour Une Histoire Des Villes Du Sud-Est Asiatique.” Annales ESC 4:842-56.

Lombard, D. (1996). Nusa Jawa Silang Budaya, Jaringan Asia. Jakarta: Gramedia Pustaka Utama.

McKinnon, E. E., Hasan D., \& Soeroso MP. (1994). “Tarumanagara? A Note on Discoveries at Batujaya and Cibuaya, West Java." in the 15th Indo-Pacific Prehistory Association Congress. Chiang Mai, 
5-12 January 1994.

Michrob, H. (1987). “A Hypothetical Reconstruction of the Islamic City of Banten.” University of Pennsylvania, Philladelphia.

Moens, J. L. (1937). "Crlvijaya, Yava En Kataha.” BKI 77:317-486.

Moens, J. L. (1940). "Was Pūrnavarman van Taruma een Saura?” Tijdschrift Voor Indische Taal-, LandEn Volkenkunde 80:78-109.

Montana, S. (1988). "Situasi Di Banten Pada Masa Pra-Geger Cilegon”, Proceedings Seminar Geger Cilegon 1888." Pp. 13-28 in Proceedings Seminar Geger Cilegon 1888, Peranan Pejuang Banten Melawan Penjajah Belanda, edited by Hasan Muarif Ambary \& Halwany Michrob. Serang, Banten.

Mundardjito, Hasan M. A., \& Hasan D. (1978). “Laporan Penelitian Arkeologi Banten 1976.” Berita Penelitian Arkeologi 18.

Noorduyn, J., \& H. T. Verstappen. (1972). "Pūrnavarman's River-Works near Tugu." Bijdragen Tot de Taal-, Land-En Volkenkunde 128 (1/3):298-307.

Novamalaisari, Elyya \& Hermawan, Z. (2014). Penyusunan Profil Ekosistem Pegunungan Akarsari Dalam Rangka Konservasi dan Rehabilitasi Kerusakan Sumberdaya Alam Propinsi Banten, Serang: Badan Lingkungan Hidup Daerah, Provinsi Banten, 2014: pp. XXVII-XXVIII.

Nurhakim, Lukman, and Moh Ali Fadillah. 1990. "Lada, Politik Ekonomi Banten Di Lampung." Pp. 258-73 in Proceedings Analisis Hasil Penelitian Arkeologi II Bali, Kajian Agrikultur Berdasarkan Data Arkeologi. Jakarta: Pusat Penelitian Arkeologi Nasional.

Pelliot, P. (1904). "Deux Itinéraires de Chine En Inde à La Fin Du VIIIe Siècle.” BEFEO 4:130-413.

Pigeaud, Th. G. Th., and H. J. De Graaf. (1976). Islamic States in Java 1500-1700, A Summary Bibliography and Index. The Hague: Martinus Nijhoff.

Polanyi, Karl. (1957). "Ports of Trade in the Eastern Mediterranean." in Trade and Market in the Early Empires, edited by and H. W. P. Polanyi, K., CM. Arenburg. New York: McMillan.

Qomaruzzaman-Anees, B. (2020). "Bercermin Pada Sejarah Banten Tempo Dulu." Pp. 47-56 in Dua Dasawarsa Pembentukan Provinsi Banten, edited by Firman Hadiansyah. Serang-Banten: Dinas Perpustakaan dan Kearsipan Provinsi Banten \& Untirta Press.

Rantoandro, G. (1995). "Lieux de Rencontre Particuliers de l'ancien Banten: Les Pabean.” Archipel 50:25-39.

Reid, A. (1988). Southeast Asia in the Age of Commerce 1450-1680. Vol. 2. New Haven - London: Yale University Press.

Reid, A. (1990). "An 'Age of Commerce' in Southeast Asian History.” Modern Asian Studies 24 (1):130.

Reid, A. (1995). "Humans and Forests in Pre-colonial Southeast Asia." Environment and History 1, no. 1 (February 1995): 93-110.http://www.environmentandsociety.org/node/2823.:

Reid, Anthony. 2011. Asia Tenggara dalam Kurun Niaga 1450-1680: Jaringan Perdagangan Global Asia Tenggara, II, Jakarta, Yayasan Pustaka Obor Indonesia Jakarta, 2011, transl. from Southeast Asia in the Age of Commerce 1450-1680 (1993).

Saptono, N. (2013). "Permukiman Kuno Di Kawasan Way Sekampung, Lampung Pada Masa Sriwijaya." Amerta, Jurnal Penelitian Dan Pengembangan Arkeologi 31 (2):81-150.

Schrieke, B. (1960). Indonesian Sociological Studies (I). The Hague: W. van Hoeve.

So, Billy K.L. (1998). "Dissolving Hegemony or Changing Trade Pattern? Images of Srivijaya in the Chinese Sources of the Twelfth and Thirteenth Centuries,in Journal of Southeast Asian Studies, 29 (2): 295-308 (14 pages), Published By: Cambridge University Press) . 
Soegondho, S. (1985). "The Pottery from Gilimanuk, Bali." Bulletin of the Indo-Pacific Prehistory Association 6:46-53.

Smith, M. L. (1999). 'Indianization', from the Indian Point of View: Trade and Cultural Contacts with Southeast Asia in the Early first Millenium C.E, in Journal of the Economic and Social History of the Orient, Vol. 42, No. 1 (1999), pp. 1- 26.

Sukendar, H., Ratna I. P., \& Rokhus D. A. (1982). "Laporan Survei Pandeglang Dan Ekskavasi Anyar, Jawa Barat 1979." Berita Penelitian Arkeologi 28.

Ueda, K., Sonny C. S. W., Naniek H., \& Chen S. L. (2016). "Paths to Power in the Early Stage of Colonialism: An Archaeological Study of the Sultanate of Banten, Java, Indonesia, the Seventeenth to Early Nineteenth Century." Asian Perspectives 55(1):1-32. doi: 10.1353/asi.2016.0009.

Untoro, H. O. (1995). Kapitalisme Pribumi Awal Kesultanan Banten 1522-1681 Kajian Arkeologi Ekonomi. Depok: FIB-UI.

VOC Archives 27. Reports on the pepper plantation in the highlands of Banten 1780-1781,179

VOC Archives 28. Instructions and Daghregister on the pepper plantation 1803-1804.

VOC Archives 29. Memory on the pepper plantation in the highlands of Banten 1805-1807.

Walker, M.J. et S. S. (1977). "Romano-Indian rouletted pottery in Indonesia", Mankind, 1 1, p. 39-45.

Wessing, Robert. 2011. "Tarumanagara: What's in a Name?" Journal of Southeast Asian Studies 42 (2):325-337.

Wheatley, P. (1975). "Satyanrta in Suvarnadvipa: From Reciprocity to Redistribution in Ancient Southeast Asia", in: J.A. Sabloff and C.C. Lamberg-Karlovsky (eds), Ancient Civilization and Trade, pp. 227-38. Albuquerque: University of New Mexico Press.

Wheatley, P. (1983). Nagara and Commandery: Origins of the Southeast Asian Urban Traditions. Chicago: University of Chicago, Department of Geography.

Wibisono, S., Niniek H., Arfian, S.. (2016). "Laporan Survey dan Ekskavasi Pandeglang", Jakarta: Puslit Arkenas (unpublished report).

Wisseman-Christie, J. (1995). "State Formation in Early Maritime Southeast Asia: A Consideration of the Theories and the Data." Bijdragen Tot de Taal-, Land-En Volkenkunde 151 (2):235-88. 